\title{
A Rapid Biuret Assay for Protein of Whole Fatty Tissues
}

\author{
ROBERT E. BEYER \\ Laboratory of Chemical Biology, Department of Cellular and Molecular Biology, Division of Biological Sciences, \\ The University of Michigan, Ann Arbor, Michigan 48109
}

Received August 30, 1982

\begin{abstract}
A rapid biuret procedure is described which avoids the turbidity that occurs with protein analysis of intact fatty tissues. Recovery is complete and absorbancy linear with both concentration of the soluble crystalline serum albumin standard and the volume of homogenate of a variety of tissues. This method has been used successfully for the determination of protein. concentrations of homogenates of whole rat heart, liver, kidney, brain, lung, and the following muscles: gastrocnemius, interior and exterior obliques, red and white vastus lateralis, and soleus.
\end{abstract}

Occasional erroneous absorbancy readings arising from the appearance of turbidity during analysis of protein concentrations of whole tissues with the biuret reagent may be circumvented by high-speed centrifugation or membrane filtration of the final blue solution, a step which is time consuming, cumbersome, and frcquently not effective in removing all turbidity. During a series of experiments on tissues of aged, sedentary, obese male rats weighing in the vicinity of $1000 \mathrm{~g}$, we encountered the problem of turbidity as a rule rather than the exception due to the high lipid content of several of the tissues. The technique described below involves rapid lipid extraction of the tissue sample, solubilization with sodium deoxycholate and $20 \mathrm{kC}$ sonic treatment, and rapid development of the blue copper-protein complex with heat. Recovery of homogenate protein and soluble standard is virtually complete and the intensity of color developed is linear with the volume of homogenate assayed. This method has been used successfully to determine the protein concentrations of the following tissues of rats from 2 to 28 months of age: heart, liver, kidney, brain, lung, and gastrocnemius, oblique, vastus lateralis, and soleus muscles.

Tissues were removed under sodium pentobarbital anesthesia $(40 \mathrm{mg} / \mathrm{kg}$ ip) and chilled in ice-cold buffer or distilled water. The tissue was weighed, minced, and homogenized with a Willems Ultra-Turrax, Type TP18/2, in two or five times its weight of cold solution. Aliquots of each tissue and crystalline bovine serum albumin (Type A-4378, Sigma Chemical Co.), in triplicate or sextuplicate (cf. Table 1), were pipetted into test tubes, $3 \mathrm{ml}$ of acetone:petrolcum ether $\left(\mathrm{BR} 35-60^{\circ} \mathrm{C}\right), 1: 1$, was added and the contents vortexed for $30 \mathrm{~s}$. The concentration of the bovine serum albumin solution $(31.25 \mathrm{mg} / \mathrm{ml})$ was standardized by the procedure of Kaziro et al. (1). Test tubes were centrifuged in a tabletop clinical centrifuge at full speed for $5 \mathrm{~min}$, the acetone:petroleum ether decanted, and the tubes drained. Ten percent sodium deoxycholate $(0.1 \mathrm{ml}), \mathrm{pH} 8.0$, and $2.9 \mathrm{ml}$ of biuret reagent prepared according to Watters' (2) modification of Gornall et al. (3) were added, the top sealed with parafilm, and the contents of the tubes mixed by gentle inversions. The contents of the tubes were subjected to two 15 -s periods of sonic treatment at $20 \mathrm{KC}$ with a Branson Sonifier tapered microtip attachment set at No. 2 power output. The tubes were placed in a boiling water bath for $30 \mathrm{~s}$ for full color development, cooled to room temperature in ice, and the absorbance read at $540 \mathrm{~nm}$ against a reagent blank containing an equivalent amount of sodium deoxycholate and biuret reagent. 


\section{TABLE 1}

Comparison of Methods for the Determination of Protein Concentrations OF TISSUES FROM A 26-MONTH-OLD RAT ${ }^{a}$

\begin{tabular}{|c|c|c|c|}
\hline \multirow[b]{2}{*}{ Tissue } & \multicolumn{3}{|c|}{ Protein, $\mathrm{mg} / \mathrm{g}$ wet wt, mean $\pm \operatorname{SEM}^{b}(N=6)$} \\
\hline & Watters (2) & Present & Lowry et al. (4) \\
\hline Heart & $100.90 \pm 4.04$ & $83.64 \pm 0.52$ & $84.75 \pm 1.69$ \\
\hline Liver & $122.04 \pm 7.66$ & $102.92 \pm 1.14$ & $104.13 \pm 1.84$ \\
\hline Kidney & $55.93 \pm 3.88$ & $51.38 \pm 0.48$ & $50.74 \pm 0.64$ \\
\hline Brain & $63.45 \pm 3.78$ & $44.45 \pm 1.04$ & $42.80 \pm 1.15$ \\
\hline Lung & $62.45 \pm 3.71$ & $57.21 \pm 1.17$ & $57.95 \pm 0.74$ \\
\hline Gastrocnemius $^{d}$ & $55.35 \pm 2.82$ & $72.03 \pm 1.09$ & $71.82 \pm 1.10$ \\
\hline Interior and exterior oblique & $90.36 \pm 3.85$ & $77.62 \pm 1.57$ & $76.17 \pm 0.92$ \\
\hline Red vastus lateralis & $97.99 \pm 8.52$ & $80.96 \pm 3.48$ & $82.20 \pm 2.97$ \\
\hline White vastus lateralis & $74.26 \pm 3.37$ & $63.24 \pm 0.57$ & $64.73 \pm 0.79$ \\
\hline Soleus $^{d}$ & $58.62 \pm 2.18$ & $56.65 \pm 1.79$ & $56.82 \pm 1.42$ \\
\hline
\end{tabular}

${ }^{a}$ All assays using the present method and that of Watters (2) were performed on $50 \mu$ l of homogenate containing tissue plus a volume of water equal to two times the wet weight of the tissue ( $3 \times$ dilution) except for red vastus lateralis and soleus, where the volume of water was equal to five times the wet weight of the tissue ( $6 \times$ dilution).

${ }^{b} \mathrm{SEM}=\sigma_{n-1} / \sqrt{n}$.

${ }^{c}$ Due to its high sensitivity, homogenates were diluted 100 times before running samples for analysis by the method of Lowry et al. (4).

${ }^{d}$ Samples for the analysis of soleus and gastrocnemius by the Watters' method (2) were centrifuged at $105,000 \mathrm{~g}$ for $90 \mathrm{~min}$ before obtaining $A_{540}$.

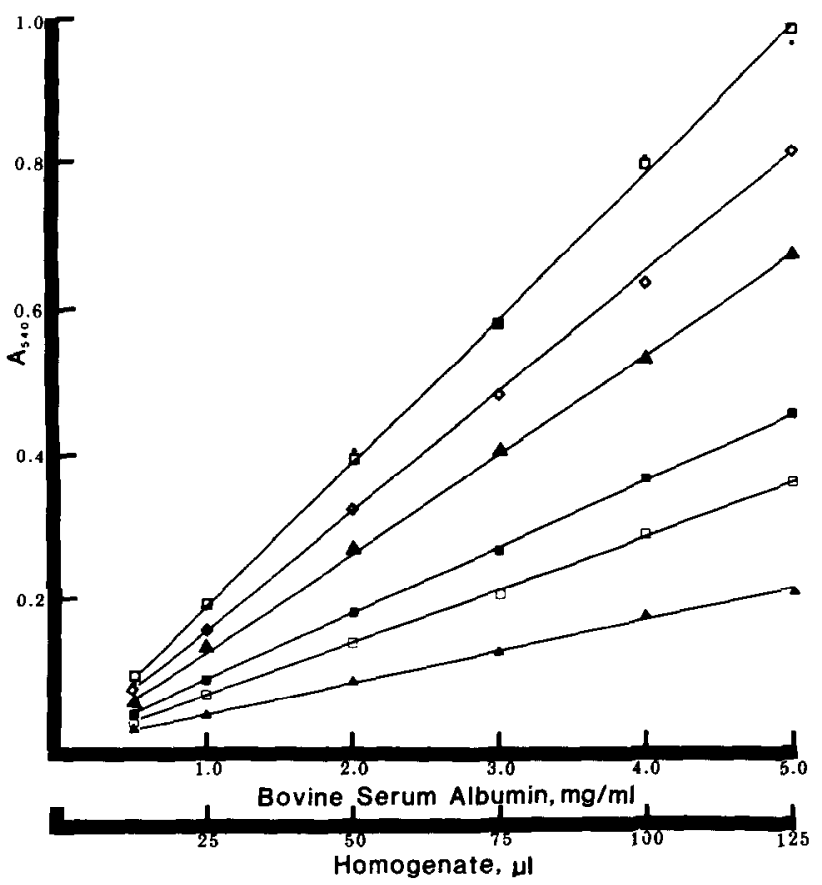

FIG. 1. Relationship between $A_{540}$ and volume of tissue homogenates and amount of bovine serum

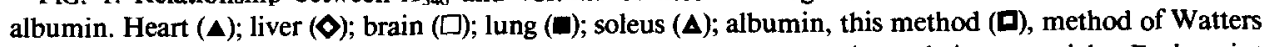
(2) $(\star)$. All tissues were homogenized with cold water equal to two times their wet weight. Each point represents the mean of three determinations. 
This procedure results in a linear relationship between absorbance at $540 \mathrm{~nm}$ and the amount of tissue homogenate or the concentration of serum albumin assayed (Fig. 1). In addition, absorbance readings for various concentrations of bovine serum albumin using both the method described herein and that of Watters (2) were indistinguishable (Fig. 1), suggesting virtual complete recovery of protein. The data in Fig. 1 also demonstrate the linear response obtained with several tissues from aged, obese rats.

Using this technique, the concentrations of protein of a variety of whole tissues may be determined and compared (Table 1). Agreement between results obtained using the present method and the established, accurate, and sensitive, but more laborious method of Lowry et al. (43) is excellent (Table 1). The method of Watters (2), which ordinarily is rapid, accurate, and convenient, gives spuriously high $A_{540}$ readings and low constancy when fatty tissues are used. This is evidenced by high values for both the means and the standard errors of the mean (Table 1). Lowering the values to the range obtained with the present and Lowry et al. (4) methods by high-speed centrifugation (Table 1) suggests that these high values are most likely due to turbidity. Occasional flocculence was encountered in samples of lung tissue which could be obviated by centrifugation prior to reading at
$540 \mathrm{~nm}$. This flocculence was due presumably to the extreme insolubility of lung elastin. The data in Table 1 for the present method were obtained within $2 \mathrm{~h}$ of the rat succumbing to the anesthesia and from a 26-month-old sedentary male Sprague-Dawley male rat weighing $1034.5 \mathrm{~g}$.

The modification of the biuret procedure described herein avoids the problem of turbidity encountered when analyzing fatty infiltrated tissue, resulting in erroneously high readings, by the introduction of lipid extraction, solubilization of protein with the aid of detergent and sonication, and rapid color development with heat. In addition, a comparison of the data in Fig. 1 herein and Fig. 1 of Ref. (2) indicates an increase in sensitivity with the present method.

\section{ACKNOWLEDGMENT}

I thank Mr. Yung Shik Rhee for verifying the efficacy of the method reported herein.

\section{REFERENCES}

1. Kaziro, Y., Ochoa, S., Warner, R. C., and Chen, J.-Y. (1961) J. Biol. Chem. 236, 1917-1923.

2. Watters, C. (1978) Anal. Biochem. 88, 695-698.

3. Gornall, A. G., Bardawill, C. J., and David, M. M. (1949) J. Biol. Chem. 117, 751-766.

4. Lowry, O. H., Rosebrough, N. J., Farr, A. L., and Randall, R. J. (1951) J. Biol. Chem. 193, 265275. 